\title{
Testikulární nádory
}

\author{
Nikol Rušarová, Hana Študentová, Marie Bartoušková \\ Onkologická klinika Fakultní nemocnice Olomouc
}

Germinální nádory jsou nejčastější malignity diagnostikované u mladých mužů. Poslední roky, stejně jako u řady dalších malignit, jeví incidence stoupající trend, ale zejména díky mezioborové spolupráci urologů s klinickými onkology je léčba těchto pacientů velmi úspěšná. Jedná se o skupinu nádorů s velmi dobrou prognózou a i u pokročilého onemocnění může být řada pacientů zcela vyléčena.

Klíčová slova: germinální nádory, seminom, neseminom, chemoterapie, inguinální orchiektomie.

\section{Testicular tumours}

Germ cell tumours are the most common malignancies diagnosed in young men. In the recent years, as is also the case with a number of other malignancies, their incidence appears to have an increasing trend; however, particularly due to interdisciplinary collaboration of urologists and clinical oncologists, the treatment of these patients is very successful. It is a group of tumours with a very good prognosis and, even in the case of advanced disease, many patients can be cured completely.

Key words: germ cell tumours, seminoma, non-seminoma, chemotherapy, inguinal.

\section{Úvod}

Germinální nádory varlat patří díky své biologické povaze k nádorům s dobrou prognózou, přičemž pětileté přežití se $v$ dnešní době pohybuje okolo $95 \%$. Jedná se o nádory vysoce chemosenzitivní. $\vee 70$. letech 20. století se testikulární nádory podílely z 11 \% na všech úmrtích na nádorové onemocnění a pětileté přežití bylo pouhých $64 \%$. Faktory, které se bezpochyby podílely na snížení mortality, jsou zejména vývoj a použití účinné protinádorové chemoterapie, dostupnost sérových onkomarkerů a zlepšení chirurgické techniky. Tyto nádory se nejčastěji vyskytují u mužů mezi 15 a 35 lety a tvoři okolo $1 \%$ všech solidních tumorů, vyskytujících se u mužského pohlaví. Pro léčebné účely rozeznáváme dvě hlavní široké kategorie histologických typů, tzv. seminom a všechny ostatní typy označované jako neseminomové nádory. Diagnostickým a léčebným výkonem u těchto typů nádorového onemocnění je vysoká inguinální orchiektomie.

\section{Epidemiologie a rizikové faktory}

Epidemiologické důkazy naznačují, že incidence GCTs (Germ cell tumors - GCTs) se celosvětově zvyšuje od počátku 20. století a má dvouvrcholový charakter (obrázek 1). V roce 2016 bylo v České republice zaznamenáno 498 nových onemocnění (incidence 9,59/100 000 mužů) (1). Nejvyšší incidence je u dětí okolo 4 let věku a u mužů s věkovým rozmezím mezi 15 a 35 lety, s rostoucím věkem se jejich incidence snižuje. Nádory ze zárodečných buněk představují 95 \% histologických typů, které se mohou ve varleti vyskytnout. Ve zbývajících $5 \%$ se jedná o lymfom, karcinoid, gonadoblastom, prípadně metastatické postižení při jiném nádorovém onemocnění (2). Testikulární nádory se obvykle projevují jako rezistence či nebolestivý edém jednoho z varlat. Př́znaky mohou být doprovázeny bolestí břicha či skrota. Je známo několik faktorů podílejících se na zvýšeném riziku vzniku testikulárních nádorů. Patři mezi ně kryptorchismus, hypospadie, rodinný výskyt nádorů varlat, neplodnost či HIV infekce $(3,4)$. Inguinální kryptorchismus vede k malignitě s menší pravděpodobností než v prípadě uložení varlat v dutině břišní (5).

\section{Histologie a klasifikace}

Patologie testikulárních nádorů zahrnuje poměrně značné spektrum histologických podtypů s rozlišným klinickým a biologickým chováním. Biologické chování nádoru závisí mimo jiné také na věku pacienta a primární lokalizaci nádoru (testikulární vs. extragonadální lokalizace), nebot i histologicky identické nádory mohou mít odlišné biologické chování v závislosti na těchto parametrech. Často složitá klasifikační schémata se mohou stát zdrojem zmatku a v mnoha prípadech může být histologické hodnocení velmi subjektivnía může docházet k morfologickému prèekrývání různých podtypů nádorů (6). GCTs Ize dělit na seminomy a neseminomy (nonseminom germ cell tumors NSGCT), kam patří všechny ostatní typy nádorů 
Obr. 1. Incidence a mortalita

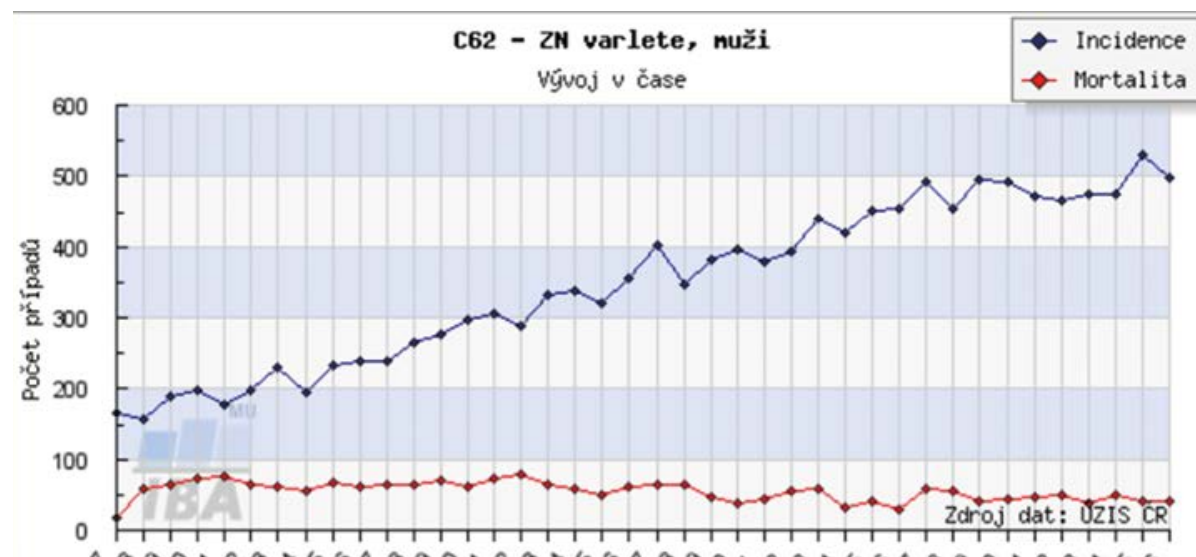

Â

Analyzov aná data: $\mathrm{N}($ inc $)=13909 . \mathrm{N}(\mathrm{mor})=2178$

Zdroj: wwW.svod.cz

Obr. 2. WHO klasifikace tumorů varlete

\begin{tabular}{|c|c|c|c|}
\hline \multirow{2}{*}{\multicolumn{2}{|c|}{ Germ cell tumours derived from germ cell }} & \multicolumn{2}{|l|}{ Granulosa cell tumour } \\
\hline & & Adult granulosa cell tumour & $8620 / 1$ \\
\hline \multicolumn{2}{|l|}{ Non-invasive germ cell neoplasia } & Juvenile granulosa cell tumour & $8622 / 1^{*}$ \\
\hline Germ cell neoplasia in situ & $9064 / 2$ & \multirow{2}{*}{\multicolumn{2}{|c|}{ Mixed and unclassified sex cord-stromal tumours }} \\
\hline \multicolumn{2}{|c|}{ Specific forms of intratubular germ cell neoplasia } & & \\
\hline \multicolumn{2}{|c|}{ Tumours of a single histological type (pure forms) } & Mixed sex cord-stromal tumour & $8592 / 1$ \\
\hline $\begin{array}{l}\text { Seminoma } \\
\text { Seminoma with syncytiotrophoblast cells } \\
\text { Non-seminomatous germ cell fumours }\end{array}$ & $9061 / 3$ & $\begin{array}{l}\text { Unclassified sex cord-stromal tumour } \\
\text { Tumour containing both germ cell and } \\
\text { sex cord-stromal elements }\end{array}$ & $8591 / 1$ \\
\hline Embryonal carcinoma & $9070 / 3$ & Gonadoblastoma & $9073 / 1$ \\
\hline Yolk sac tumour, postpubertal-type & $9071 / 3$ & & \\
\hline \multicolumn{2}{|l|}{ Trophoblastic tumours } & \multicolumn{2}{|l|}{ Miscellaneous tumours of the testis } \\
\hline Choriocarcinoma & $9100 / 3$ & Ovarian epithelial-type tumours & \\
\hline Non-choriocarcinomatous & & Serous cystadenoma & $8441 / 0$ \\
\hline trophoblastic tumours & & Serous tumour of borderline malignancy & $8442 / 1$ \\
\hline Placental site trophoblastic tumour & $9104 / 1$ & Serous cystadenocarcinoma & $8441 / 3$ \\
\hline Epithelioid trophoblastic tumour & $9105 / 3$ & Mucinous cystadenoma & $8470 / 0$ \\
\hline Cystic trophoblastic tumour & & Mucinous borderline tumour & $8472 / 1$ \\
\hline Teratoma, postpubertal-type & $9080 / 3$ & Mucinous cystadenocarcinoma & $8470 / 3$ \\
\hline Teratoma with somatic-type malignancy & $9084 / 3$ & Endometrioid adenocarcinoma & $8380 / 3$ \\
\hline \multicolumn{2}{|l|}{ Non-seminomatous germ cell tumours of more } & Clear cell adenocarcinoma & $8310 / 3$ \\
\hline than one histological type & & Brenner tumour & $9000 / 0$ \\
\hline Mixed germ cell tumours & $9085 / 3$ & Juvenile xanthogranuloma & \\
\hline \multicolumn{2}{|l|}{ Germ cell tumours of unknown type } & Haemangioma & $9120 / 0$ \\
\hline Regressed germ cell tumours & $9080 / 1$ & Haematolymohoid tumours & \\
\hline \multirow{2}{*}{\multicolumn{2}{|c|}{$\begin{array}{l}\text { Germ cell tumours unrelated to germ cell } \\
\text { neoplasia in situ }\end{array}$}} & Diffuse large B-cell lymphoma & $9680 / 3$ \\
\hline & & Follicular lymphoma, NOS & $9690 / 3$ \\
\hline Spermatocytic tumour & $9063 / 3$ & Extranodal NKT-cell lymphoma, nasal-type & $9719 / 3$ \\
\hline Teratoma, prepubertal-type & $9084 / 0$ & Plasmacytoma & $9734 / 3$ \\
\hline Dermoid cyst & & Myeloid sarcoma & $9930 / 3$ \\
\hline Epidermoid cyst & & Rosai-Dorfman disease & \\
\hline $\begin{array}{l}\text { Well-differentiated neuroendocrine tumour } \\
\text { (monodermal teratoma) }\end{array}$ & $8240 / 3$ & e testis & \\
\hline \multirow{2}{*}{\multicolumn{2}{|c|}{ Mixed teratoma and yolk sac tumour. }} & Adenoma & $8140 / 0$ \\
\hline & $9085 / 3$ & Adenocarcinoma & $8140 / 3$ \\
\hline Yolk sac tumour, prepubertal-type & $9071 / 3$ & & \\
\hline \multicolumn{2}{|l|}{ Sex cord-stromal tumours } & \multicolumn{2}{|c|}{$\begin{array}{l}\text { The morphology codes are from the international Classification of Diseasen } \\
\text { tor Oncology }(\mathrm{CD}-0)(917 \mathrm{~A}) \text {. Behawiour is coded /O for benign tumours; }\end{array}$} \\
\hline Leydig cell tumour & $8650 / 1$ & \multicolumn{2}{|c|}{ I1 for unspecfed, borderline, $\alpha$ uncertain behaviour. 12 for carcinoma in } \\
\hline Malignant Leydig cell tumour & $8650 / 3$ & \multicolumn{2}{|c|}{ stu and grade III intraepithelial neoplasia; and 3 for malignant tumours. } \\
\hline Sertoli cell tumour & $8640 / 1$ & \multirow{2}{*}{\multicolumn{2}{|c|}{$\begin{array}{l}\text { The classification is modified trom the previous WHO classilicasion (756A). } \\
\text { taking into account changos in our understanding of these lesions. }\end{array}$}} \\
\hline Malignant Sertoli cell tumour & $8640 / 3$ & & \\
\hline \multirow{2}{*}{$\begin{array}{l}\text { Large cell calcifying Sertoli cell tumour } \\
\text { Intratubular large cell hyalinizing Sertoli } \\
\text { cell neoplasia }\end{array}$} & $8642 / 1$ & \multicolumn{2}{|c|}{ "New code approved by the LARCMHO Cormititee for ICD-O. } \\
\hline & $8643 / 1^{*}$ & & \\
\hline
\end{tabular}

Zdroj: Holger Moch, et al. European Urology Volume 2016; 70(1): 93-105.

a jsou složeny z jednoho nebo více histologických podtypů. Seminomy tvoří přibližně $50 \%$ všech testikulárních nádorů a současně je seminomová složka součástí NSGCT až ve 20 \% prípadů (7). V diferenciální diagnostice Ize seminom zaměnit s lymfomem ev. s embryonálním karcinomem. Mezi NSGCT patří embryonální karcinom, teratokarcinom, choriokarcinom, nádor ze žloutkového váčku a smíšené nádory (obrázek 2) (8).

\section{Klinické projevy}

Prvním přiznakem bývá rezistence případně nebolestivý edém jednoho z varlat, který je jako první zaznamenán pacientem prípadně sexuálním partnerem (9). 30 \% pacientů si při klinickém vyšetření stěžuje na bolest v podbřišku, v perianální oblasti, nebo pocitují pnutí v oblasti skrota. Další symptomy často souvisí s lokalizací metastatického postižení. Může se objevit kašel a postupně se zhoršující dušnost v prípadě výskytu plicních metastáz, nebo bolesti zad při masivní retroperitoneální lymfadenopatii či metastatickém postižení kostí a páteře. Až u 5 \% pacientů doprovází symptomy gynekomastie. Gynekomastie u těchto pacientů je systémovou endokrinní manifestací a je obvykle spojena s produkcí lidského choriového gonadotropinu (hCG - human chorionic gonadotropin). Lidský choriový gonadotropin je produkován v buňkách choriokarcinomu nebo v trofoblastických buňkách nádoru (10). V príipadě výrazné nadprodukce hCG může dojít až k rozvoji paraneoplastické hypertyreózy. Lidský choriový gonadotropin a TSH mají společnou alfa a beta podjednotku z čehož vyplývá, že hCG má jistou slabou aktivitu ve stimulaci štítné žlázy (11). Nejčastější lokalizace germinálních nádorů je varle. Nicméně některé typy GCTs se vyskytují primárně extragonadálně na místech jako je mediastinum, retroperitoneum nebo centrální nervový systém bez primární testikulární lokalizace. Patogeneze výskytu extragonadálních GCT není plně objasněna (12).

\section{Diagnostika}

Na prvním místě prí diagnostice testikulárního nádoru je fyzikální vyšetření. Fyzikální vyšetření by mělo začít na kontralaterálním zdravém varleti, aby vyšetřující lékař měl relativní pojem o velikosti, obrysu a konzistenci zdravého varlete. Normální zdravé varle má homogenní konzistenci, je volně pohyblivé a oddělitelné od nadvarlete. Testikulární nádory mají tendenci zůstávat vejčitého tvaru, často omezené obalem tunica albuginea. Nicméně rozšíření nádorového postižení do nadvarlete se vyskytuje až u 10 \% pacientů.

Diagnostickým postupem následujícím po fyzikálním vyšetření je ultrazvukové vyšetření skrota, které může pomoci rozlišit jiné patologické jednotky, jež se mohou vyskytovat ve varleti. V diferenciální diagnostice testikulárních nádorů hraje významnou roli zejména torze varlete, epididymitida, hydrokéla, varikokéla nebo hematom (13). V dalším kroku se odebírají onkomarkery ( $\beta$-hCG, AFP a LDH). Sérové koncentrace AFP (a-fetoprotein) a/nebo $\beta$-hCG jsou zvýšeny v $80 \%$ u pacientů s NSGCT. Ačkoliv tyto markery mohou podpořit diagnózu v počáteční fázi diagnostické rozvahy a jsou užitečné pro stanovení prognózy, jejich hlavní role je při 
Tab. 1. Sérové koncentrace nádorových markerů

\begin{tabular}{|l|l|l|l|}
\hline & AFP & $\boldsymbol{\beta}$-hCG & LDH \\
\hline S0 & v normě & v normě & v normě \\
\hline S1 & $<1000 \mathrm{ng} / \mathrm{ml}$ & $<5000 \mathrm{IU} / \mathrm{l}(1000 \mathrm{ng} / \mathrm{ml})$ & $<1,5 \times \mathrm{N}$ \\
\hline S2 & $\geq 1000 \mathrm{a} \leq 10000 \mathrm{ng} / \mathrm{ml}$ & nebo $\geq 5000 \mathrm{IU} / \mathrm{l} \mathrm{a} \leq 50000 \mathrm{IU} / \mathrm{L}$ & nebo $\geq 1,5 \times \mathrm{a} \leq 10 \times \mathrm{N}$ \\
\hline S3 & $>10000 \mathrm{ng} / \mathrm{ml}$ & nebo $>50000 \mathrm{IU} / \mathrm{l}(10000 \mathrm{ng} / \mathrm{ml})$ & nebo $>10 \times \mathrm{N}$ \\
\hline
\end{tabular}

Zdroj: AJCC Cancer Staging Manual, Eighth Edition (2017; Springer International Publishing)

sledování reakce na léčbu a při detekci možné recidivy onemocnění. Rozsah zvýšení hladin v séru u těchto vybraných markerů je důležitým prognostickým ukazatelem u pacientů s GCTs. Tato informace je součástí mezinárodního systému stratifikace rizika a součástí stagingu TNM. Hodnota S je stanovována pomocí těchto 3 markerů, viz tabulka 1 (14).

Tyto onkomarkery by nikdy neměly být použity samostatně pro stanovení diagnózy GCTs, nicméně jsou používány pro podporu stanovení diagnostiky GCTs. Nádorové buňky produkují molekulu hCG, v séru však stanovujeme jeho $\beta$-podjednotku, nebot a-podjednotka je společná s několika hormony hypofýzy. $\beta$-hCG je nejčastěji zvýšený nádorový marker při výskytu testikulárních nádorů. Produkce $\beta$-hCG u NSGCT se mění v závislosti na nádorovém postižení a histologických podtypech zastoupených v nádoru. Poločas rozpadu $\beta$-hCG je 1,5-3 dny, což je důležité zejména proto, že rychlá normalizace hodnot po orchiektomii naznačuje eliminaci nádoru a perzistence naopak svědčí pro prítomnost reziduální nemoci $(15,16)$. AFP je běžně produkován fetálním žloutkovým váčkem a u zdravých mužů je v séru nedetekovatelný. Zvýšené hladiny AFP se vyskytují téměř výhradně u pacientů s NSGCT a při výskytu hepatocelulárního karcinomu, zatímco u pacientů se seminomy bývá hladina AFP v mezích normy. Poločas rozpadu AFP je 5 až 7 dnů a falešně pozitivní zvýšení hladiny AFP se vyskytuje při cirhotické přestavbě jaterního parenchymu či při alkoholismu a při zvýšeném abusu drog (17). Zvýšená koncentrace laktátdehydrogenázy (LDH) je asi u 50 \% mužů s testikulárním nádorem. LDH patří mezi méně senzitivní a specifický nádorový marker, než je AFP a $\beta$-hCG, nicméně může být také jediným markerem, který je elevovaný u pacientů se seminomy. Stupeň elevace LDH v séru má prognostickou hodnotu (18).

Diagnostickým a terapeutickým výkonem je vysoká inguinální orchiektomie eventuálně doplněna o retroperitoneální disekci lymfatických uzlin. Transskrotální biopsie je kontraindikována, nebot může vést ke zvýšenému výskytu lokoregionálních relapsů či může vést ke zvýšenému riziku metastatického postižení inguinálních uzlin. Vysoká inguinální orchiektomie jednak stanoví definitivní histologickou diagnózu GCTs a může být také definitivní léčbou primárního nádoru (19).

K určení rozsahu onemocnění je standardně prováděno $C T$ vyšetření. K vyšetření hrudníku postačí RTG vyšetření, nicméně při abnormálním nálezu je doporučováno provedení i CT vyšetření. MR břicha a pánve je obvykle zbytečná, nebot’ nepřidá více informací než CT břicha. MR mozku bývá doporučováno v prípadě neurologické symptomatologie nebo při extrémně vysokých hladinách hCG svědčící pro prítomnost choriokarcinomové složky (20). PET-CT je častěji využíváno u pacientů se seminomy ke zhodnocení viability postchemoterapeutických reziduí. Nejrozsáhlejší údaje o využití PET-CT v diagnostice testikulárních nádorů pocházejí z multicentrické studie SEMPET (21).

\section{Screening}

Je obecně známo, že screeningové vyšetření vede k odhalení asymptomatického nádorového procesu se zvýšeným potenciálem k vyléčení a vede ke snížení morbidity a mortality daného onemocnění. Vzhledem k tomu, že GCTs mají v celkovém měřítku velmi nízkou incidenci

Tab. 2. Prognostická klasifikace

\begin{tabular}{|c|c|c|}
\hline & Seminomy & Non-seminomy \\
\hline Příznivá prognóza & $\begin{array}{l}\text { Jakákoliv primární lokalizace, plicní } \\
\text { metastázy/metastázy v lymfatických } \\
\text { uzlinách (LU), normální AFP, jakékoli } \\
\beta \text {-hCG, jakékoliv LDH }\end{array}$ & $\begin{array}{l}\text { Primární lokalizace ve varleti/ } \\
\text { retroperitoneu, metastázy plicní a/nebo } \\
\text { v lymfatických uzlinách, AFP }<1000 \text { ng/ } \\
\text { ml, } \beta \text {-hCG }<5000 \text { IU/l a LDH }<1,5 \times \mathrm{N}\end{array}$ \\
\hline Střední prognóza & $\begin{array}{l}\text { Jakákoliv primární lokalizace, viscerální } \\
\text { metastázy (i jiné než plicní), normální AFP, } \\
\text { jakékoli } \beta \text {-hCG, jakékoliv LDH }\end{array}$ & $\begin{array}{l}\text { Primární lokalizace ve varleti/ } \\
\text { retroperitoneu a bez viscerálních } \\
\text { metastáz (kromě plicních) a hodnoty } \\
\text { markerů - kterýkoliv z: AFP } \geq 1000 \\
a \leq 10000 \mathrm{ng} / \mathrm{ml} \text { nebo } \beta-\mathrm{hCG} \geq 5000 \mathrm{IU} / \mathrm{I} \\
\mathrm{a} \leq 50000 \mathrm{IU} / \mathrm{I} \text { nebo } \mathrm{LDG} \geq 1,5 \times \mathrm{N} \\
\mathrm{a} \leq 10 \times \mathrm{N}\end{array}$ \\
\hline Špatná prognóza & Není & $\begin{array}{l}\text { Primární lokalizace v mediastinu nebo } \\
\text { viscerální metastázy (jiné než plicní) nebo } \\
\text { následující hodnoty markerů jakékoliv z: } \\
\text { AFP }<10000 \mathrm{ng} / \mathrm{ml} \text { nebo } \beta \text {-hCG }>50000 \\
\text { IU/l }(10000 \mathrm{\mu g} / \mathrm{ml} \text { ) nebo } \mathrm{LDH}>10 \times \mathrm{N}\end{array}$ \\
\hline
\end{tabular}

Zdroj: George J. Bosl et al., N Eng/ J Med 1997; 337: 242-254 s vysokou mírou vyléčených pacientů je velmi nepravděpodobné, že by screening pro testikulární nádory našel své opodstatnění. Dalším faktorem, který by měl být rozhodujícím při zavedení screeningového vyšetření pro určitý typ onemocnění je to, zda-li je významný rozdíl mezi morbiditou a mortalitou u pacientů diagnostikovaných v počátečním stadiu onemocnění na rozdíl od těch pacientů, kterým je onemocnění diagnostikováno v pozdějším stadiu (22). Co se týče testikulárních nádorů, pak míra vyléčení u pacientů s pokročilým či metastatickým onemocněním je velmi vysoká. Tudíž potenciál, že by screening u pacientů s testikulárními nádory snízil morbiditu a mortalitu, je velmi nízký. Onkomarkery odebírané při GCTs jsou sice velmi přinosné a jsou hojně využívány pro stanovení prognózy onemocnění a sledování efektu léčby, nicméně mají nízkou specificitu a nedostatečnou senzitivitu, aby mohly být použivány $\checkmark$ rámci screeningového vyšetření (23). Vyšetření kontralaterálního varlete by mělo být prováděno minimálně $1 x$ měsičně $z$ důvodu vyšší incidence kontralaterálního nádoru varlete u pacientů s již prodělaným GCTs či u pacientů léčených pro extragonadální germinální tumory.

\section{Adjuvantní léčba}

Testikulární nádory mohou sestávat z jednoho nebo více histologických typů onemocnění. Všem pacientům před zahájením léčby by měla být nabídnuta možnost kryoprezervace spermií. Spermiogram u pacientů s testikulárním nádorem je často spojen se základním postižením spermatogeneze. Mechanismus účinku většiny cytotoxických látek je jejich interference s buněčnými procesy, které zahrnují syntézu DNA 
v rychle se dělících nádorových buňkách, včetně buněk podílejících se na spermatogenezi. Tato porucha spermatogeneze se vyskytuje až u 50 \% pacientů, nicméně mechanismus spojení mezi spermatogenezí a nádorem varlat není znám, nebot’ spermiogram je u těchto pacientů porušen ještě před podáním chemoterapie. Následné podstoupení chemoterapie může dále vést k dalšímu narušení fertility (24).

\section{Seminom}

Pacienti se seminomem v nízkém stadiu mají vynikající prognózu a již více než 85 \% pacientů se seminomem stadia I je vyléčeno radikální inguinální orchiektomií. Pacientům, kteří nejsou schopni a ochotni dodržovat kroky nutné při aktivním sledování, je možné adjuvantně podat karboplatinu AUC 7, eventuálně Ize provést adjuvantní radioterapii na oblast paraaortálních uzlin s doporučenou dávkou 20 Gy (25). U pacientů, u kterých Ize předpokládat dobrou spolupráci, je možné využít aktivní sledování vzhledem k vynikající prognóze tohoto stadia onemocnění. Obecně platí, že vhodnými kandidáty aktivního sledování jsou pacienti s klinickým stadiem pT1 a pT2, u pacientů s NSGCT v prípadě normalizace hodnot onkomarkerů po orchiektomii, při histologické absenci buněk ze žloutkového váčku. Hlavním prínosem aktivního sledování je vyhnutí se léčbě a souvisejících nežádoucích účinků. Ovšem nevýhodou u tohoto typu terapie je opakované provádění zobrazovacích vyšetření spojených s poměrně značnou radiační zátěží. Nejlépe stanoveným rizikovým faktorem, který mưže u seminomu způsobit relaps je velikost tumoru. Některé studie dále uváději jako významný rizikový faktor pro relaps seminomu invazi do rete testis (26). Vzhledem k tomu, že seminomové nádory často nezvyšují hladiny testikulárních tumormarkerů, nepatří stanovování hladin onkomarkerů mezi hlavní součásti aktivního sledování (27).

Přibližně $15 \%$ pacientů se seminomem je diagnostikováno ve stadiu Il. Seminomové nádory patří mezi onemocnění velmi citlivé na chemoterapii, a dokonce i muži s pokročilým onemocněním jsou klasifikování mezi pacienty s dobrým rizikem onemocnění dle IGCCCG (International Germ Cell Cancer Collaborative Group). U tohoto stadia onemocnění se preferuje podání kombinované chemoterapie, je doporučováno podání 3 cyklů kombinované chemoterapie BEP (bleomycin, etoposid a cisplatina). U většiny pacientů je prefe- rován režim BEP, nicméně u pacientů s predisponujícím plicním postižením je adekvátním podání 4 cyklů režimu EP. U pacientů se středním rizikem, u kterých není předpokládané riziko projevư toxicity bleomycinu je doporučováno podání 4 cyklů režimu BEP, eventuálně při kontraindikaci bleomycinu je možné zvolit režim VIP (cisplatina, ifosfamid a etoposid) (28). V případě podávání chemoterapie by měla být dodržována dávková intenzita režimu po celou dobu léčby, nebot snížení dávek má za následek horší výsledky. Dávková intenzita by měla být dodržována i bez ohledu na počet leukocytů při zahájení dalšího cyklu. U pacientů s dobrým rizikem je doporučováno používat růstové faktory pouze v prípadě, že předchozí cyklus byl komplikován febrilní neutropenií (29). Po chemoterapii následuje zobrazovací metoda (nejčastěji CT nebo PET-CT). V prípadě přetrvávání viabilní nádorové tkáně (elevace onkomarkerů, akumulace radiofarmaka na PET-CT) je preferovanou možností chirurgický výkon (21). $\checkmark$ prípadě normalizace onkomarkerů (v podstatě jen $\beta$-hCG, LDH je málo specifickým markerem, AFP není seminomy produkováno) společně s abnormálním nálezem na zobrazovacích metodách Ize tyto nádorové masy zrídkakdy považovat za viabilní a v 50 \% prípadů dojde k úplné remisi onemocnění během prvního roku sledování (30).

\section{Neseminom}

I u pacientů s neseminomovým typem nádoru platí, že tyto nádory jsou citlivější na chemoterapii než většina solidních nádorů vyskytující se u dospělých pacientů. Největší prospěch z adjuvantní léčby mají pacienti s lymfovaskulární invazí (LVI) nádoru, dále pacienti s rozsahem nádoru T3-T4, v prípadě dominance složky embryonálního karcinomu a u nádorů u nichž došlo k širrení do skrota (31). Při neprítomnosti těchto rizikových faktorů je riziko relapsu 10-14 \% a v prípadě výskytu těchto faktorů je míra recidivy onemocnění až 40-55 \% (tabulka 2). Pacienti ve stadiu I mohou být léčeni adjuvantní chemoterapií BEP, Ize provést disekci retroperitoneálních lymfatických uzlin (RPLND) nebo při neprítomnosti rizikových faktorů je možné zvolit aktivní sledování. V př́padě prítomnosti těchto rizikových faktorů není aktivní sledování vhodným způsobem léčby. Ve studii fáze III bylo srovnáváno podání 1 cyklu BEP a jednostranné retroperitoneální lymfadenektomie, po mediánu sledování 4,7 let byly v rameni s chemoterapií 2 relapsy onemocnění ve srovnání se 13 relapsy u pacientů s provedenou lymfadenektomií (32). V další prospektivní studii SWENOTECA byli zařazeni pacienti s NSGCT ve stadiu I s nebo bez LVI. Všem pacientům byl podán 1 cyklus BEP, u pacientů s LVI byla 5letá míra relapsu 3,2\% a u pacientů bez LVI 1,6\%. Pětiletý medián celkového přežití byl v obou skupinách $100 \%$. Několik dalších studií volilo v adjuvantním podání 2 cykly BEP, nicméně u těchto pacientů došlo k výrazným projevưm pozdní toxicity chemoterapie, zejména s velkým podílem kardiotoxicity, ototoxicity a projevům neuropatie. Základním doporučením v prípadě podávání chemoterapie u pacientů s NSGCT stadia I je tedy podání 1 cyklu BEP, nicméně lze říci, že LVI je signifikantním prediktorem relapsu po orchiektomii. RPLND zůstává rozumnou alternativou k chemoterapii, zejména u mužů s teratomem, který má tendenci k lokálnímu šîrení, je ale poměrně málo citlivý k chemoterapii. RPLND je bezpečnou metodou s nízkým výskytem erektilní dysfunkce a je spolehlivou metodou pro zjištění presného stagingu onemocnění v oblasti lymfatických uzlin. $V$ prípadě RPLND se podstatně snižuje počet pacientů podstupujících chemoterapii, nicméně až u 20\% pacientů mưže definitivní histologie mít za následek nutnost podání 2 cyklů BEP/EP (33).

Ve stadiu II došlo k rozšiření nádoru do lymfatických uzlin bezjiných vzdálených metastáz nebo výrazného zvýšení nádorových markerů (S0-S1). Pacienti ve stadiu II A (lymfatické uzliny velikosti do 2 cm a S0-1) by měli být standardně léčeni 3 cykly BEP nebo 4 cykly EP alternativou k chemoterapii je RPLND. Pacienti ve stadiu II B (lymfatické uzliny 2-5 cm, S0-1) a II C (lymfatické uzliny nad $5 \mathrm{~cm}$, S0-1) by měli být léčeni 4 cykly BEP (34). Podstatná část pacientů ve stadiu II B a II C může mít přitomnu reziduální nemoc po léčbě chemoterapií. V tomto případě je možné indikovat RPLND, eventuálně u spolupracujících pacientů je možné volit aktivní sledování (zejména u ložisek velikosti < 1 cm) (35). U pacientů s reziduem v klinickém stadiu II B a II C je vhodnější metodou další podání chemoterapie, nejčastěji 2 cykly BEP nebo EP. Nebyly provedeny srovnávající studie pro tyto dva režimy u pacientů s reziduem po chemoterapii, nicméně riziko relapsu je približně $1 \%$ režimu BEP i EP (36). Navzdory přiznivějšímu profilu toxicity by cisplatina neměla být rutině nahrazována karboplatinou. Ačkoli karboplatina je méně nefrotoxická než cisplatina, proběhly 4 randomizované studie prímo porovnávajíci účinnost karboplatiny a cisplatiny u pacientů 
s GCT. Tyto studie jasně prokázaly nižší účinek karboplatiny u tohoto typu nádorového onemocnění (37-40). U pacientů s NSGCT neexistuje shoda při léčbě postchemoterapeutického rezidua (potvrzeného zobrazovacími metodami, elevace onkomarkerů po chemoterapii), které se vyskytuje až u 25-30\% pacientů. Většina z těchto nálezů je v oblasti retroperitonea. I zde je na místě možno indikovat chirurgický výkon (RPLND u lézí větších než $1 \mathrm{~cm}$ ), prípadně pokračovat chemoterapií. $\checkmark$ prípadě kompletní resekce reziduálních hmot, při výskytu méně než 10 \% viabilních nádorových buněk nebo u pacientůs príznivou prognózou lze chemoterapii odložit a zvolit observaci, protože tito pacienti mají více než $90 \%$ pětileté přežití bez progrese.

\section{Léčba recidivujícího onemocnění}

Recidiva GCT je nejčastěji zachycena při odběru onkomarkerů a poté potvrzena zobrazovacími metodami. Onkomarkery bývají zvýšeny u více než poloviny pacientů. U pacientů se seminomy se až třetina relapsů vyskytne po více než 3 letech od ukončení léčby, kdežto u pacientů s NSGCT se $95 \%$ relapsů objeví v prvních dvou letech po orchiektomii. V současné době neexistuji žádné randomizované studie, které by přesně definovaly strategii sledování u pacientů s anamnézou testikulárního nádoru. V prípadě recidivy GCT je další chemoterapie volena na základě předchozí léčby. Po předléčení kombinovanou chemoterapií BEP je v dalš́l linii volen režim TIP (ifosfamid, cisplatina a paklitaxel) podávaný ve 4 cyklech, nebo režim VelP (vinblastin, ifosfamid, cisplatina) ve 4 cyklech. I u těchto režimů se stále kurabilita onemocnění pohybuje okolo 90 \% u pacientů se špatnou prognózou se pak míra vyléčení pohybuje pod $50 \%$. Za př́znivé faktory při recidivě onemocnění patří odpověd' na predchozí chemoterapii (dosažení CR/PR), nízké hodnoty onkomarkerů, délka trvání úvodní remise, místo primární lokalizace nádoru a histologie. U pacientů, kteří mají progresi po léčbě platinovým derivátem (během jednoho měsíce od ukončení počáteční chemoterapie, prì progresi na druhé linii) je onemocnění

\section{LITERATURA}

1. Dušek L, Mužík J, Kubásek M, et al. Epidemiologie zhoubných nádorů v České republice [on-line]. Masarykova univerzita, [2005], [cit. 2018-10-28]. Dostupnýz URL: < http://www.svod.cz>. 2. Stevenson SM, Lowrance WT. Epidemiology and Diagnosis of Testis Cancer. Urol Clin North Am 2015; 42: 269-275. považováno za platina rezistentní. Tito pacienti mají špatnou prognózu. Mezi paliativní režimy radíme kombinovanou chemoterapii GEMOX (gemcitabin, oxaliplatina) a režim PAGE (paklitaxel, gemcitabin) (41). Jako vysoce paliativní režim je možné u vysoce predléčených pacientů volit etoposid v perorální formě, který je dostupný pouze po schválení revizním lékaře. Co se týče vysokodávkové chemoterapie (high-dose chemotherapy, HDT), tak prozatím není tato léčba standardně doporučována a je zapotřebí randomizované studie, které by porovnávaly konvenční dávku chemoterapie s HDT (42).

\section{Komplikace a nežádoucí účinky léčby}

Chemoterapie založená na bázi platiny je poměrně dobře snášena. Mezi nejčastější nežádoucí účinek patří CINV (chemotherapy-induced nausea and vomiting) s nutností adekvátní antiemetické profylaxe (5-HT3 a NK1 antagonista), nefrotoxicita s nutností intenzivní hydratace a hematologická toxicita. Ta dosahuje svého maxima druhý a třetí týden cyklu. V prípadě, že neutropenie přetrvává i při začátku dalšího cyklu je doporučováno podání chemoterapie bez redukce dávek, pokud se během minulého cyklu nevyskytla febrilní neutropenie.

Nejzávažnější komplikací spojenou s režimem BEP je plicní toxicita bleomycinu. Incidence plicní toxicity stoupá při překročení dávky 400 × 103 IU. Prediktivními faktory, které mohou zvyšovat riziko plicního postižení je vyšší věk, radioterapie na oblast hrudní stěny, predisponující plicní onemocnění jako je astma bronchiale, CHOPN a vyšší riziko mají také pacienti s kuřáckou anamnézou. Nejčastějšími př́znaky, které mohou předcházet rozvoji plicní fibrózy či pneumonitidy po bleomycinu patři námahová dušnost, neproduktivní kašel a poslechový nález. Výskyt fatální plicní toxicity je príi podání 4 cyklů 1-2\% a klesá pod $1 \%$ v prípadě podání 3 cyklů (43).

Nejvýraznější toxicitou cisplatiny je bezpochyby její vliv na renální funkce. Navzdory zásadní hydrataci pacienta pred, během i po podání cisplatiny dojde u malého počtu pacientů k po-

3. Siegel RL, Miller KD, Jemal A. Cancer statistics, 2018. CA Cancer J Clin 2018; 68: 7-30.

4. Raman JD, Nobert CF, Goldstein M. Increased incidence of testicular cancer in men presenting with infertility and abnormal semen analysis. J Urol 2005; 174: 1819-1822. klesu glomerulární filtrace a výraznému zhoršen renálních funkcí včetně iontové dysbalance (44). Mimo nefrotoxicitu cisplatina způsobuje axonální neuropatii. Častým projevem jsou parestézie a dysestézie, které začínají v prstech končetin a šíři se proximálně. Neuropatie u většiny pacientů postupně odezní, ačkoli její vymizení je mnohdy neúplné (45). Dalším běžným neurologickým pří znakem souvisejícím s léčbou platinového derivátu je ototoxicita, která se manifestuje tinnitem a ztrátou sluchu. Audiometrií může být zjištěna ztráta sluchu o téměř $90 \%$. Riziko ototoxicity indukované cisplatinou je závislé jak na dávce, tak na čase (46).

Mezi jeden z pozdních důsledků chemoterapie se řadí kardiovaskulární toxicita zahrnující zejména dyslipidemii, hypertenzi, časnou aterosklerózu, Raynaudův fenomén a trombembolické príhody (47). Vzhledem ke zvýšenému riziku kardiovaskulárních komplikací je vhodné pacienty po léčbě pro GCTs sledovat a v prípadě záchytu arteriální hypertenze inned zahájit adekvátní léčbu.

Na našem pracovišti je všem pacientům standardně před zahájením chemoterapie nabízena možnost kryoprezervace spermatu. K posouzení plicních funkcí všichni pacienti podstupují spirometrii a v prípadě zhoršení ventilačních parametrů a obavy z toxicity bleomycinu volíme režim EP. Dále je doplňována dynamická scintigrafie ledvin k posouzení funkce ledvin před zahájením chemoterapie s cisplatinou vzhledem k její potenciální výrazné nefrotoxicitě.

\section{Závěr}

Germinální nádory zaujímají mezi solidními nádory výjimečné postavení díky své vysoké kurabilitě i v prípadě diseminovaného onemocnění. Režimy chemoterapie založené na cisplatině mohou vyléčit až $80 \%$ pacientů s metastatickým onemocněním včetně pacientů s viscerálními metastázami. Vzhledem k tomu, že se ve většině prípadů jedná o mladé nemocné, hraje významnou roli i pozdní toxicita chemoterapie a radioterapie, včetně možnosti vzniku sekundárních malignit či kardiovaskulární morbidity. Z tohoto důvodu je snaha o redukci počtů cyklů adjuvantní chemoterapie a odklon od radioterapie.

5. Oh J, Landman J, Evers A, et al. Management of the postpubertal patient with cryptorchidism: an updated analysis. J Urol 2002; 167: 1329-1333.

6. Ulbright TM. The most common, clinically significant misdiagnoses in testicular tumor pathology, and how to avoid 


\section{| PŘEHLEDOVÉ ČLÁNKY}

\section{TESTIKULÁRNÍ NÁDORY}

them. Adv Anat Pathol 2008; 15: 18-27.

7. Howitt BE, Berney DM. Tumors of the Testis: Morphologic Features and Molecular Alterations. Surg Pathol Clin 2015; 8: 687-716.

8. Mostofi FK, Sesterhenn IA, Davis CJ Jr. Developments in histopathology of testicular germ cell tumors. Semin Urol 1988; 6: 171-182.

9. Bosl GJ, Motzer RJ. Testicular germ-cell cancer. N Engl J Med 1997; 337: 242-254

10. Tseng A Jr, Horning SJ, Freiha FS, et al. Gynecomastia in testicular cancer patients. Prognostic and therapeutic implications. Cancer 1985; 56: 2534-2538.

11. Oosting SF, de Haas EC, Links TP, et al. Prevalence of paraneoplastic hyperthyroidism in patients with metastatic non-seminomatous germ-cell tumors. Ann Oncol 2010; 21: 104-108.

12. McKenney JK, Heerema-McKenney A, Rouse RV. Extragonadal germ cell tumors: a review with emphasis on pathologic features, clinical prognostic variables, and differential diagnostic considerations. Adv Anat Pathol 2007; 14: 69-92. 13. Benson CB. The role of ultrasound in diagnosis and staging of testicular cancer. Semin Urol 1988; 6: 189-202.

14. International Germ Cell Consensus Classification: a prognostic factor-based staging system for metastatic germ cell cancers. International Germ Cell Cancer Collaborative Group. J Clin Oncol 1997; 15: 594-603.

15. Hori K, Uematsu K, Yasoshima H, et al. Testicular seminoma with human chorionic gonadotropin production. Pathol Int 1997; 47: 592-599.

16. Stenman UH, Alfthan H, Hotakainen K. Human chorionic gonadotropin in cancer. Clin Biochem 2004; 37: 549-561. 17. Gilligan TD, Seidenfeld J, Basch EM, et al. American Society of Clinical Oncology Clinical Practice Guideline on uses of serum tumor markers in adult males with germ cell tumors. J Clin Oncol 2010; 28: 3388-3404.

18. Mencel PJ, Motzer RJ, Mazumdar M, et al. Advanced seminoma: treatment results, survival, and prognostic factors in 142 patients. J Clin Oncol 1994; 12: 120-126.

19. Schmoll HJ, Souchon R, Krege S, et al. European consensus on diagnosis and treatment of germ cell cancer: a report of the European Germ Cell Cancer Consensus Group (EGCCCG). Ann Oncol 2004; 15: 1377-1399.

20. Novotný J, Vítek P, a Kleibl Z. Onkologie v klinické praxi: standardní prístupy $v$ diagnostice a léčbě vybraných zhoubných nádorů. 2. vydání. Praha: Mladá fronta, 2016

21. De Santis M, Becherer A, Bokemeyer C, et al. 2-18fluoro-deoxy-D-glucose positron emission tomography is a reliable predictor for viable tumor in postchemotherapy seminoma: an update of the prospective multicentric SEMPET trial. J Clin Oncol 2004; 22: 1034-1039.

22. Ilic D, Misso ML. Screening for testicular cancer. Cochra- ne Database Syst Rev 2011; CD 007853.

23. Mir MC, Pavan N, Gonzalgo ML. Current Clinical Applications of Testicular Cancer Biomarkers. Urol Clin North Am 2016; 43: 119-125

24. Petersen PM, Skakkebaek NE, Vistisen K, et al. Semen quality and reproductive hormones before orchiectomy in men with testicular cancer. J Clin Oncol 1999; 17: 941-947.

25. Stenning S, Oliver T, Mead B, Gabe R. Carboplatin in clinical stage I seminoma: a valuable option for patient management. J Clin Oncol 2011; 29: 4210-4219.

26. Yu HY, Madison RA, Setodji CM, et al. Quality of surveillance for stage I testis cancer in the community. J Clin Oncol 2009: 27: 4327-4332.

27. Vesprini D, Chung P, Tolan S, et al. Utility of serum tumor markers during surveillance for stage I seminoma. Cancer 2012; 118: 5245-5250.

28. De Wit R, Roberts J, Wilkinson PM, et al. Equivalence of three or four cycles of bleomycin, etoposide, and cisplatin chemotherapy and of a 3or 5-day schedule in good-prognosis germ cell cancer: a randomized study of the European Organization for Research and Treatment of Cancer Genitourinary Tract Cancer Cooperative Group and the Medical Research Council. J Clin Oncol, 2001; 19: 1629-1640.

29. Fossa SD, Kaye SB, Mead GM, et al. filgrastim during combination chemotherapy of patients with poor prognosis metastatic germ cell malignancy. European Organization for Research and Treatment of Cancer Genitourinary Group and the Medical Research Council Testicular Cancer Working Party. J Clin Oncol, 1998; 16: 716-724.

30. Flechon A, Bompas E, Biron P, Droz JP. Management of post-chemotherapy residual masses in advanced seminoma. J Urol 2002; 168(5):1975-1979.

31. Hermans BP, Sweeney CJ, Foster RS, et al. Risk of systemic metastases in clinical stage I nonseminoma germ cell testis tumor managed by retroperitoneal lymph node dissection. J Urol 2000; 163: 1721-1724

32. Alberts P, Siener R, Krege S, et al. Randomized phase III trial comparing retroperitoneal lymph node dissection with one course of bleomycin and etoposin plus cisplatin chemotherapy in the adjuvant treatment of clinical stage I nonseminomatous testicular germ cell tumors: AUO trial AH 01/94 by the German Testicular Cancer Study Group. J Clin Oncol 2008; 26: 2966-2972. 33. Tandstad T, Dahl O, Cohn-Cedermark G, et al. Risk-adapted treatment in clinical stage I nonseminomatous germ cell testicular cancer: the SWENOTECA management program. J Clin Oncol 2009; 27: 2122-2128.

34. Kondagunta GV, Motzer RJ. Adjuvant chemotherapy for stage II nonseminomatous germ cell tumors. Urol Clin North Am 2007; 34: 179-185.

35. Ravi P, Gray KP, O'Donnell EK, et al. A meta-analysis of patient outcomes with subcentimeter disease after chemothe- rapy for metastatic non-seminomatous germ cell tumor. Ann Oncol 2014; 25(2): 331-338

36. Williams SD, Stablein DM, Einhorn LH, et al. Immediate adjuvant chemotherapy versus observation with treatment at relapse in pathological stage II testicular cancer. N Engl J Med 1987; 317(23): 1433-1438.

37. Tjulandin SA, Garin AM, Mescheryakov AA, et al. Cisplatin-etoposide and carboplatin-etoposide induction chemotherapy for good-risk patients with germ cell tumors. Ann Oncol 1993; 4: 663-667.

38. Bajorin DF, Sarosdy MF, Pfister DG, et al. Randomized trial of etoposide and cisplatin versus etoposide and carboplatin in patients with good-risk germ cell tumors: a multiinstitutional study. J Clin Oncol 1993; 11: 598-606.

39. Bokemeyer C, Köhrmann O, Tischler J, et al. A randomized trial of cisplatin, etoposide and bleomycin (PEB) versus carboplatin, etoposide and bleomycin (CEB) for patients with 'good-risk' metastatic non-seminomatous germ cell tumors. Ann Oncol 1996; 7: 1015-1021.

40. Horwich A, Sleijfer DT, Fosså SD, et al. Randomized trial of bleomycin, etoposide, and cisplatin compared with bleomycin, etoposide, and carboplatin in good-prognosis metastatic nonseminomatous germ cell cancer: a Multiinstitutional Medical Research Council/European Organization for Research and Treatment of Cancer Trial. J Clin Oncol 1997; 15: 1844-1852. 41. Kollmannsberger C, Beyer J, Liersch R, et al. Combination chemotherapy with gemcitabine plus oxaliplatin in patients with intensively pretreated or refraktory germ cell cancer:A study of the German Testicular Cancer Study Group, Clin Oncol. 2004; 22: 108-114.

42. Feldman DR, Huddart R, Hall E, et al. Is high dose therapy superior to conventional dose therapy as initial treatment for relapsed germ cell tumors? The TIGER Trial. J Cancer 2011; 2: 374-377.

43. Jules-Elysee K, White DA. Bleomycin-induced pulmonary toxicity. Clin Chest Med 1990; 11: 1-20.

44. Vogelzang NJ, Torkelson JL, Kennedy BJ. Hypomagnesemia, renal dysfunction, and Raynaud's phenomenon in patients treated with cisplatin, vinblastine, and bleomycin. Cancer 1985; 56: 2765-2770.

45. Glendenning $J$, Barbachano Y, Norman AR, et al. Long-term neurologic and peripheral vascular toxicity after chemotherapy treatment of testicular cancer. Cancer 2010; 116: 2322-2331.

46. Frisina RD, Wheeler HE, Fossa SD, et al. Comprehensive Audiometric Analysis of Hearing Impairment and Tinnitus After Cisplatin-Based Chemotherapy in Survivors of Adult-Onset Cancer. J Clin Oncol 2016; 34: 2712-2720.

47. van den Belt-Dusebout AW, Nuver J, de Wit R, et al. Long-term risk of cardiovascular disease in 5-year survivors of testicular cancer. J Clin Oncol 2006; 24: 467-475. 